\title{
Update on the etiopathogenesis of psoriasis (Review)
}

\author{
DACIANA ELENA BRANISTEANU ${ }^{1 *}$, CATALINA COJOCARU $^{2}$, ROXANA DIACONU ${ }^{2}$, \\ ELENA ANDRESE PORUMB $^{3 *}$, ANISIA IULIANA ALEXA ${ }^{4 *}$, ALIN CODRUT NICOLESCU ${ }^{5}$, \\ ILARIE BRIHAN $^{6}$, CAMELIA MARGARETA BOGDANICI ${ }^{4}$, GEORGE BRANISTEANU ${ }^{7}$, \\ ANDREEA DIMITRIU $^{8}$, MIHAIL ZEMBA $^{9}$, NICOLETA ANTON ${ }^{4}$, MIHAELA PAULA TOADER $^{10}$, \\ ADRIAN GRECHIN $^{11}$ and DANIEL CONSTANTIN BRANISTEANU ${ }^{4}$ \\ ${ }^{1}$ Department of Dermatology, 'Grigore T. Popa' University of Medicine and Pharmacy, \\ 700115 Iasi; ${ }^{2}$ Department of Dermatology, Railway Clinical Hospital, 700506 Iasi; \\ ${ }^{3}$ Department of Dermatology, 'Sf. Spiridon' Clinical Emergency County Hospital, 700111 Iasi; \\ ${ }^{4}$ Department of Ophthalmology, 'Grigore T. Popa' University of Medicine and Pharmacy, 700115 Iasi; \\ ${ }^{5}$ Department of Dermatology, 'Roma' Medical Center for Diagnosis and Treatment, 011773 Bucharest; \\ ${ }^{6}$ Department of Dermatology, Dermatology Clinic, Faculty of Medicine and Pharmacy, University of \\ Oradea, 410073 Oradea; ${ }^{7}$ Faculty of Medicine, 'Grigore T. Popa' University of Medicine and Pharmacy, \\ 700115 Iasi; ${ }^{8}$ Department of Dermatology, 'Arcadia' Hospitals and Medical Centers, 700620 Iasi; \\ ${ }^{9}$ Department of Ophthalmology, 'Carol Davila' University of Medicine and Pharmacy, 020021 Bucharest; \\ ${ }^{10}$ Department of Oral Dermatology, 'Grigore T. Popa' University of Medicine and Pharmacy, 700115 Iasi; \\ ${ }^{11}$ Department of Ophthalmology, 'Sf. Spiridon' Clinical Emergency County Hospital, 700111 Iasi, Romania
}

Received October 22, 2021; Accepted November 22, 2021

DOI: $10.3892 / \mathrm{etm} .2022 .11124$

\begin{abstract}
Psoriasis is one of the most common immunemediated chronic inflammatory skin disorders, involving hyperproliferative keratinocytes and infiltration of $\mathrm{T}$ cells, dendritic cells, macrophages, and neutrophils. Multiple factors appear to play important roles in the pathogenesis of psoriasis. These environmental (e.g., infectious agents and trauma), genetic, and immunologic factors are reviewed in this article. Although the pathogenesis of psoriasis remains to be established, data suggesting immune cell dysregulation in the skin are available. The involvement of the immune system, particularly $\mathrm{T}$ cells, in the etiopathogenesis of psoriasis is discussed in this review, indicating a potential justification for innovative treatment intervention. Besides describing pathogenic $\mathrm{T}$ cells,
\end{abstract}

Correspondence to: Dr Catalina Cojocaru, Department of Dermatology, Railway Clinical Hospital, 1 Garabet Ibraileanu Street, 700506 Iasi, Romania

E-mail: cj.catalina@yahoo.com

Dr Mihail Zemba, Department of Ophthalmology, 'Carol Davila' University of Medicine and Pharmacy, 37 Dionisie Lupu Street, District 2, 020021 Bucharest, Romania

E-mail:mhlzmb@yahoo.com

*Contributed equally

Key words: psoriasis, etiopathogenesis, immunity, lymphocytes, cytokines, tissue resident memory cells, biologic therapies the aim of the review was to assess the function of newly identified antimicrobial peptides (AMPs), interleukin (IL)-23, IL-17, and tissue resident memory cells (TRMs), and their role in psoriasis. Furthermore, new insights were presented regarding TRMs, a recently identified subset of memory T cells, and the role they play in the local memory of disease, making them a potential new therapeutic target in psoriasis. Finally, current developments in T-cell research and cytokine-targeted therapy for psoriasis treatment are reviewed.

\section{Contents}

1. Introduction

2. Research methods

3. Epidemiology

4. Etiology

5. Pathogenesis

6. Conclusions

\section{Introduction}

Psoriasis is a chronic inflammatory cutaneous condition that causes the development of scaly, indurated, erythematous plaques on the skin. The three main histologic characteristics of psoriasis are epidermal hyperplasia, proliferation of dermal blood vessels, and an inflammatory infiltrate of leukocytes, primarily in the dermis (1).

Psoriasis is a papulosquamous skin disease that was once assumed to be mainly an epidermal keratinocyte issue, but is 
now recognized among the most typical immune-mediated disorders (2). Antimicrobial peptides (AMPs), dendritic cells (DCs), tumor necrosis factor (TNF), IL-23, Th17, IL-17, IL-22, signal transducer and activator of transcription (STAT)3, and tissue resident memory cells (TRMs) contribute substantially to its pathogenesis (1). The identification of this additional subset of helper T cells (Th17) and Th22 cells, as well as their distinct sets of cytokines [interleukin (IL)-23, and IL-22], has paved the way for the development of more novel, more targeted treatments.

Although early hypotheses of the pathogenesis of psoriasis mainly aimed to examine keratinocyte hyperproliferation, dysregulation of the immune system is now acknowledged to be a crucial event in this disease. Increasing knowledge of the role played by the immune system in psoriasis has greatly affected the development of treatment. Many new and emerging therapeutic agents target specific immunologic aspects of psoriatic disease.

Subsequent findings have shown that interactions between DCs, T cells, keratinocytes, neutrophils, TRMs and the cytokines released from immune cells contribute to the initiation and perpetuation of the cutaneous inflammation that is attributed to psoriasis (3). The development of psoriasis is the subject of this review.

\section{Research methods}

To collect reports of psoriasis etiopathogeny, a literature search was conducted using electronic databases Google Scholar, PubMed, Key Elsevier, UpToDate and Medscape for the terms 'psoriasis' in combination with 'etiology', 'pathogenesis', 'skin immunity', 'T cells', 'tissue resident memory cells', and 'cytokines'. A search only for relevant published literature was conducted and the most recent papers and authoritative articles that emerged from 2015 to September 2021, were selected. Articles deemed irrelevant to the aim of this literature review or beyond the research scope were excluded. Thus, prospective, retrospective, literature review-type articles and human observational and experimental studies, restricted to the English language were included. Based on 179 publications found in the literature, a concise report was compiled.

\section{Epidemiology}

Psoriasis is a relatively common disorder that occurs in children and adults worldwide. There is no clear sex predilection for psoriasis $(4,5)$. Both males and females are affected by psoriasis, with females and those with a family history having an earlier onset. It has a bimodal age of onset, with peaks in men at 30-39 years and 60-69 years, and 10 years earlier in women (6). Psoriasis can start at any age; however, it is more common in adults than in children.

Psoriasis prevalence ranges from 0.5 to $11.4 \%$ in adults and 0 to $1.4 \%$ in children, according to a systematic worldwide review (7). Psoriasis affects an estimated 60 million individuals globally. It is more prevalent in high-income areas and locations with an aging population (6). The variation in prevalence of psoriasis appears to depend on distance from the equator, with population located closer to the equator (Egypt, Tanzania, Sri Lanka, Taiwan) being less affected by the disease than those countries further away from it (Europe and Australia) (4).

\section{Etiology}

Psoriasis is a multifactorial disease in which both extrinsic and intrinsic factors play major roles. Genetic predisposition is considered a key contributor, especially in individuals with early onset of the disease (under 40 years) $(8,9)$.

Behavioral and environmental factors may also be involved. Mild localized trauma (10), stress (11), drugs (12), infections (13), smoking and alcohol usage (14), obesity (15), are all known to cause or aggravate psoriasis. Climate change in general, and exposure to natural sunlight in particular, has been recognized as a possible psoriasis trigger or exacerbating factor (16).

Genetics is one of the most significant factors. The importance of genetic factors is demonstrated by the fact that approximately $40 \%$ of individuals with psoriasis or psoriatic arthritis have a family history of the disease (17). Additionally, monozygotic twins are more likely to have the disease than dizygotic twins (18). Using genome-wide association studies, over 60 susceptibility loci have been identified, many of which contain genes involved in immune system regulation (8).

The psoriasis-susceptibility (PSORS1) locus on chromosome 6p21 (location of the HLA genes) is thought to be a major genetic determinant of psoriasis $(19,20)$. HLA-Cw6 is the most important allele for susceptibility to early-onset psoriasis and it has also been associated with guttate psoriasis, among other MHC genes linked to psoriasis (21). HLA-B17 has been linked to an increased risk of psoriasis and severe psoriatic arthritis (22).

Psoriasis susceptibility loci have been also found in genes that encode the common component of the IL-12 and IL-23 receptors $(23,24)$. Psoriasis appears to be predisposed to or protected by certain receptor polymorphisms $(24,25)$. Furthermore, highly associated to psoriasis are the $I L 12 B$ gene, which encodes for the p40 subunit of IL-12 and IL-23 (26), as well as the IL23A gene, which encodes for the p19 subunit of IL-23 and IL-39 (23). Despite the lack of evidence, pustular psoriasis appears to be genetically unique, with different susceptibility genes implicated (IL36RN, APIS3 in Europeans, and CARD14 in other ethnicities) $(8,27)$.

Beta blockers, lithium, and antimalarial medicines are the most commonly employed pharmaceuticals that can induce psoriasis-like eruptions or worsen the psoriasis. Notably, TNF inhibitors, which are commonly used to treat psoriasis, have also been associated with the development of psoriasis-like eruptions (28-31).

Infections, both bacterial and viral, have been linked to worsening of psoriasis. The initiation or exacerbation of psoriasis in correlation with HIV infection, as well as poststreptococcal flares of guttate psoriasis, are known contributors (13).

Low vitamin D levels have been observed in psoriasis patients, although the function of vitamin D in psoriasis is unknown (32). Even after adjusting for factors such as the Fitzpatrick skin phototype and estimated sun exposure, serum levels of 25-hydroxyvitamin D were lower in the patients with psoriasis in a case-control study that compared 
43 patients with psoriasis and 43 matched controls with other non-photosensitive dermatologic diseases (33).

For many psoriatic patients, psychological distress is a causal or sustaining component in disease manifestation (34). In a previous study comprising 400 patients with newly developed psoriasis, $46 \%$ of plaque psoriasis patients and $12 \%$ of guttate psoriasis patients associated the onset of their disease to a life crisis, such as divorce, severe or life-threatening disease in the patient or a family member, death in the family, financial burden, dismissal, or harassment in school (11). Further research is necessary to determine the effect of stress on the progression of psoriasis.

\section{Pathogenesis}

Psoriasis was essentially considered a disease of epidermal keratinocyte proliferation until the early 1980s, with the cutaneous inflammatory infiltration as a later occurrence. However, there is now compelling evidence that the cellmediated adaptive immune response is critical in the treatment of psoriasis (2).

The idea of psoriasis being simply a T helper (Th)1-mediated disorder has been replaced by the hypothesis of an inflammatory disease that is mediated by Th1 and Th17 $(35,36)$. In psoriatic lesions, decreased suppressive activity of regulatory T cells (Tregs) may lead to uncontrolled action of other effector cells (36). As a result, rather than being a disease caused by a single subset of $\mathrm{T}$ cells, psoriasis is more clearly understood as the result of intricate interactions among numerous subsets of T cells.

The immunologic events that are thought to occur in psoriasis are outlined in a simple sequence as follows (3). i) The activation of plasmacytoid dendritic cells (pDCs) and other innate immune cells in the skin is promoted by antigenic stimuli. ii) Interferon (IFN)- $\alpha$ and other proinflammatory cytokines generated by innate immune cells increase the activation and migration of various myeloid dendritic cells (mDCs) in the skin. iii) T lymphocytes are attracted to, differentiated, and activated by cytokines produced by mDCs, particularly IL-23. iv) T cells that have been recruited generate cytokines, the most significant of which is IL-17A, which acts in concert with other cytokines to stimulate keratinocyte proliferation and the production of proinflammatory AMPs and cytokines. v) Immune cells and keratinocytes produce cytokines, which participate in positive feedback loops to keep the inflammatory process in progress $(35,37)$.

AMPs, DCs, TNF, IL-23, Th17, IL-17, IL-22, and STAT3 contribute substantially to the pathogenesis of psoriasis. The identification of an additional subset of helper $\mathrm{T}$ cells (Th17), Th1 and Th22 cells, as well as their distinct sets of cytokines (IL-23, IL-12, and IL-22), has paved the way for the development of more novel and targeted treatments.

AMPs. AMPs are comprised of 12-50 amino acids, have a positive charge, and have an amphipathic structure. They help protect the host by destroying harmful bacteria, protozoa, fungus, and viruses $(38,39)$. AMPs act as chemotactic agents, angiogenic factors, and cell proliferation regulators, affecting host inflammatory responses (39). In psoriasis, certain AMPs, including S100 proteins, cathelicidins and beta-defensins are overexpressed and secreted by keratinocytes, macrophages and neutrophils in response to injury and cytokine stimulation (40).

The S100 proteins are a group of low-molecular-weight proteins (9-13 kDa) (41). Psoriasis patients have high levels of S100A7 (psoriasin), S100A8 (calgranulin A), S100A9 (calgranulin B), S100A12 (calgranulin C), and S100A15 (calgranulin C) (42). The expression of beta-defensin 2, S100A9, S100A7, and S100A8 was enhanced synergistically by the combination of IL-22, IL-17A, IL-17F, and keratinocytes (43). In psoriasis, S100A7 (psoriasin) has been found to be a strong and selective chemotactic inflammatory protein for T cells and neutrophils (44).

Defensins are cationic microbicidal peptides that are divided into three categories, i.e., $\alpha, \beta$ and $\gamma$ (42). The $\alpha$-defensins are also classified into six subtypes known as human neutrophil peptides (HNPs) 1-6. HNPs 1-3 are present in the scales of psoriatic lesions (45). The $\beta$-defensins are divided into four subtypes identified as human $\beta$-defensins (hBDs) 1-4. TNF- $\alpha$ and IFN- $\gamma$ induce hBD-2 and -3 , which are abundant in psoriatic scales, while IL1-7A and IL-22 also induce hBD-2 in keratinocytes (39). The exact role of defensins in the pathophysiology of psoriasis is unknown (46).

Cathelicidin LL-37 is the C-terminal peptide fragment that originates from hCAP18 (47). Through Toll-like receptor (TLR) 9 pDCs recognize self-DNA, and LL-37 is the main component that causes pDC activation in psoriasis (48). In addition, keratinocytes are exposed to LL-37 and self-DNA generate type I IFN, which have been linked to the onset of psoriasis (49). pDCs are stimulated by LL-37 bound to RNA through TLR7 and LL-37-RNA complexes act on myeloid DCs (mDCs) through TLR8 $(40,46,49)$.

TNF, IL-23, and IL-12 are produced by activated mDCs when they move into draining lymph nodes. Slan ${ }^{+}$monocytes also react to LL-37-RNA activation and release TNF, IL-23, and IL-12 (50). IL-23 and IL-12 activate Th17 and Th1 cell subsets from naive T cells, respectively (40). Mabuchi and Hirayama verified in a study that various 9-mer peptides generated from LL-37 have significant binding affinities for HLA-C*06:02 molecules, and they hypothesized a mechanism for the interaction of LL-37 HLA-C*06:02 complexes with T cells via T-cell receptors (51).

ADAMTSL5, a protein produced from melanocytes, has been identified as an autoantigen (52). In association with HLA-C*06:02, intra-epidermal CD8 T lymphocytes identify ADAMTSL5 on melanocytes (52). With IL-17 stimulation, keratinocytes generate ADAMTSL5, and CXCL1, a neutrophil chemoattractant and melanocyte growth factor, inducing ADAMTSL5 expression (52). The number of melanocytes increases in psoriasis, and $\mathrm{T}$ cells, including cytotoxic $\mathrm{T}$ cells, co-localize with them (53). However, as the number of melanocytes increases and there are no indications of cell death in psoriasis, it is hypothesized that melanocytes are likely targets of the non-cytotoxic $\mathrm{CD}^{+} \mathrm{T}$ cell-mediated autoimmune response (54).

The pattern of T-cell infiltration and DC aggregation in the superficial dermis in psoriasis, which is analogous to LL-37 (55), is mirrored by the ADAMTSL5 expression pattern. After therapy with an IL-17 or TNF blocker, the expression of ADAMTSL5 and LL-37 with DCs, neutrophils, macrophages, 
and $\mathrm{T}$ cells in psoriasis is markedly reduced $(56,57)$. This decrease suggests that HLA-class II molecules present ADAMTSL5 and LL-37 to autoreactive CD4 ${ }^{+} \mathrm{T}$ cells, whereas HLA-Cw6*02 molecules present ADAMTSL5 and LL-37 to $\mathrm{CD} 8^{+} \mathrm{T}$ cells, both of which are expressed on the surface of antigen-presenting cells inside dermal lymphoid tissue structures $(52,57)$. In psoriasis patients, a synthetic ADAMTSL5 peptide enhances the frequency of CD8 T cells expressing IL-17A and IFN-7 among peripheral blood mononuclear cells, but this effect is not observed in healthy subjects (52).

pDCs. pDCs are important cells involved in the early stages of psoriasis. pDCs can be stimulated by viral and bacterial particles by activating Toll-like receptors (TLR)7 and TLR9, resulting in the production of type 1 interferon (IFN- $\alpha$ ) (58). IFN- $\alpha$ is a key cytokine involved in the initiation phase of autoimmune responses and antiviral immunity, causing an inflammatory response, associated with psoriasis, through the activation of mDCs $(59,60)$. IFN- $\alpha$ upregulation has been found in early psoriatic lesions (61). Furthermore, in a mouse xenograft model of psoriasis, the formation of psoriatic lesions was found to depend on IFN- $\alpha$ production by pDCs (60).

The mechanism by which pDCs generate a psoriasiform response is partly elucidated by observational experiments with imiquimod $(59,62,63)$, a synthetic imidazoquinoline recognized by TLR7 (64). pDCs are induced to produce type I IFN- $\alpha(62,63)$ and interferon regulatory factor 7 (IRF7) (65) when imiquimod is applied to the non-lesional skin of susceptible patients (63). pDCs respond in a similar way when they detect bacterial and viral peptides $(59,62,63)$.

In vivo, the antimicrobial peptide LL-37 is found to be a major activator of pDCs. It has been postulated that the release of LL-37 by activated keratinocytes and the subsequent binding of the molecule to self-DNA in susceptible individuals causes conformational changes in the bound DNA molecule, transforming this otherwise harmless molecule into an aggregated, dense structure recognized by early ribosomal TLR9, resulting in IFN- $\alpha$ production but not $\mathrm{pDC}$ maturation. As a result, LL-37-activated pDCs move into the epidermis, where they identify autoantigens produced by keratinocytes, potentially perpetuating the pathogenic process $(48,66)$. According to this theory, dysregulated LL-37 may serve as a link between keratinocytes and pDCs in the pathogenesis of psoriasis (48). Through interactions with HLA-DR and class-I alleles, LL-37 is related to the activation of both $\mathrm{CD}^{+}$and CD8 ${ }^{+}$LL37-specific psoriatic T cells (66).

$m D C s$. In psoriatic skin, the number of mDCs is significantly increased. An inflammatory subset of mDCs [including TNF- $\alpha$ and iNOS-expressing dendritic cells (TIP-DCs), 6-sulfo LacNAc dendritic cells (slanDCs), and epidermal dendritic cells (eDCs)] has been detected in lesional psoriatic skin in response to the release of IFN- $\alpha$ and other proinflammatory cytokines and chemokines $(50,67-71)$.

Once activated, $\mathrm{mDCs}$ orchestrate the inflammatory phases of psoriasis. Inflammatory mDCs also co-express cytokines such as TNF- $\alpha$, iNOS, and IL-12, which are all well-known inflammatory mediators. TNF- $\alpha$ (also released by keratinocytes) activates $\mathrm{mDCs}$ and Langerhans cells, and stimulates macrophages to convert into DCs (68).
TNF- $\alpha$ is produced by mDCs, which are powerful APCs that generate a variety of inflammatory cytokines that impact T-cell activity. IL-23, a cytokine that promotes the differentiation of precursor $\mathrm{CD} 4^{+}$cells into Th17 cells, and IL-12, a cytokine that promotes the formation of Th1 cells and effector $\mathrm{CD} 8^{+} \mathrm{T}$ cells $(50,71,72)$ are also produced by mDCs. mDCs influence keratinocytes and the skin vasculature by producing IL-20 (a keratinocyte function modifier) and nitric oxide (a vasodilator) (73).

Cytokines. The hypothesis of a cytokine network in psoriasis suggests a major involvement of proinflammatory cytokines, including TNF- $\alpha$ (74). In reflection, the clinical effectiveness of anti-TNF medication in the treatment of psoriasis has confirmed this theory (75). The major cytokines that appear to be involved in this disease, based on gene signature analysis, include type I interferons, IFN- $\gamma$, and TNF- $\alpha$ (76).

$I F N-\alpha$. In early psoriasis lesions, type I interferon pathways are upregulated (61). pDCs produce the majority of IFN- $\alpha$ in psoriatic skin. The finding that systemic therapy with IFN- $\alpha$ can aggravate psoriasis $(77,78)$ provides evidence in favor of IFN- $\alpha$, playing a significant role in psoriasis. Furthermore, topical therapy with imiquimod, which causes local IFN- $\alpha$ production in the skin, has been shown to promote the development of psoriasis in individuals and a psoriasis-like condition in mice $(79,80)$. The psoriasis-like condition develops in mice lacking a transcription factor that suppresses type I interferon signaling (81).

$T N F-\alpha$. TNF- $\alpha$ is a proinflammatory cytokine that is common in a variety of inflammatory diseases, including psoriasis (82). TNF- $\alpha$ is produced and responded to by activated dendritic cells, Th17 and Th1 cells, and keratinocytes in psoriatic skin. TNF- $\alpha$ also promotes disease development by interacting with other cytokines.

The evidence of elevated TNF- $\alpha$ levels in the lesional skin of psoriatic individuals (83), marked clinical improvement in psoriasis with pharmacologic inhibitors of TNF- $\alpha$ (infliximab, adalimumab, etanercept, and certolizumab pegol) $(75,84-87)$ and decreased numbers of dendritic and $\mathrm{T}$ cells, as well as a reduction in epidermal hyperplasia through removing circulating TNF- $\alpha$ with etanercept (a TNF- $\alpha$ inhibitor) in psoriatic skin (69), suggests that TNF- $\alpha$ plays an essential role in psoriasis. TNF- $\alpha$ is a prominent target for therapeutic inhibition because of its major involvement in both innate and adaptive immune responses.

IL-23. IL-23 produced by DCs and downstream products of helper T cells, such as IL-17A and IL-22, are also important $(88,89)$.

In psoriasis, key cytokines function via a limited number of signaling and transcriptional pathways. Cytokine-like type I interferons, IFN- $\gamma$, IL-23, IL-12, IL-22 function via Janus kinases and signal transducers and activators of transcription (JAK-STATs), while TNF- $\alpha$ operates through the NF- $\mathrm{KB}$ pathway (3).

The IL-23p19 subunit (encoded by IL-23A) and the IL-12/IL-23p40 subunit (shared with IL-12 and encoded by IL-12B) form a heterodimer. The subunit binds to the IL-23R 
receptor, which is linked to Jak 2 and Tyk2. When the receptor is activated, a signaling cascade is triggered, which includes the activation of STAT3 (90).

Evidence of IL-23 involvement in psoriatics is sustained by the fact that IL-23 levels are higher in psoriasis lesions compared to unaffected skin, and it is found in dermal DCs and keratinocytes; IL-23 levels decrease with effective psoriasis treatment (91-93). In support of this, injection of IL-23 into normal mouse skin causes clinical and histological alterations that are similar to psoriasis $(92,94,95)$. This process is dependent on the downstream generation of IL-22 and IL-17A. Furthermore, results from a mouse model revealed that, blocking IL-23 inhibited the development of psoriasis in human xenografted skin from patients with psoriasis (96).

IL-12. IL-12 is produced by activated mDCs, similar to IL-23, and it stimulates Th1 cell development. Increased Th1 cells and IFN- $\gamma$ (a product of Th1 cells) in psoriatic skin provide indirect evidence for an IL-12-related role in psoriasis $(97,98)$. The inability of a study to detect the overexpression of the IL-12 p35 subunit in psoriatic skin (88) casts doubt on the extent to which IL-12 contributes to psoriasis. Preclinical mouse studies also suggest that IL-12 has a regulatory or protective role in the IL-23/Th17 immunologic pathway (99). It is probable that ustekinumab, a type of biological therapy for psoriasis that targets both IL-12 and IL-23 (96,100), may function primarily through the drug's effects on the IL-23 pathway.

As a result, a complex and partly redundant set of psoriasisrelated cytokines converge on well-known intracellular checkpoints that are common to many chronic inflammatory diseases. T cells, in particular, are the key protagonists in the disease's development among all the diverse immunological cellular elements. In fact, the IL-23/Th17/IL-17 axis now appears to have a determining effect on the beginning of psoriasis inflammation (101).

$C D 4^{+} T$ cells. CD4 helper $\mathrm{T}$ cells are detected in dermal inflammatory infiltrates of psoriatic skin (102). An injection of CD4 (but not CD8) T cells from psoriasis patients into graft sites on SCID mice transplanted with human skin-generated psoriatic alterations in the grafted skin is evidence for a role for these cells (103). Furthermore, patients with psoriasis who were treated with monoclonal antibodies against the CD4 molecule on T cells improved clinically (104).

Psoriasis has been linked to the Th17 subset of CD4 T cells, as well as Th1 and Th22 cells to a lesser extent. Th1 cells were thought to have a dominant role in early research, but Th17 cells are now thought to play a more important role. The impact of these cells, as well as other adaptive immune system components, on psoriasis are discussed below.

Th17. The identification of Th17 cells has resulted in new target-specific therapy methods and critical insights into the pathogenesis of psoriasis. Th17 cells originate in psoriatic skin as a result of the polarizing effects of the inflammatory DC production of IL-1, IL-6, TGF- $\beta$, and IL-23 (105). Th17 cells, that have been activated by IL-23, generate IL-17A and IL-22, cytokines that promote keratinocyte activation and development $(94,106,107)$.
The following study results highlight the role of these cells in psoriasis: IL-17A is abundantly produced by Th17 cells that are observed in lesional skin and at higher levels in the circulation in psoriasis patients $(97,108,109)$. Th17 cells secrete a number of proinflammatory cytokines, including IL-17A, IL-17F, IL-21, IL-22, IL-6, and TNF- $\alpha$ (110), which have all been related to psoriasis. In fact, IL-17 is a critical cytokine in the initiation and maintenance of inflammation, as it stimulates endothelial cells and macrophages to produce pro-inflammatory cytokines (111).

Selective targeting of IL-17A (the principal effector cytokine produced by Th17 cells) with secukinumab and ixekizumab, as well as bimekizumab's dual blocking of IL-17A and IL-17F, improves psoriasis (112-114). Brodalumab, which blocks the IL-17RA portion of the IL-17A receptor, has had similar success in treating psoriatic skin (115).

IL-23, which is produced by macrophages and DCs, is important for upregulating IL-17 production by promoting Th17 survival and proliferation (116). It also appears to be necessary for keratinocytes to participate in inflammation, causing acanthosis and mixed inflammatory cell infiltration of the dermis (95). IL-23 is also responsible for increasing TNF production in macrophages.

A viable treatment method for psoriasis is by inhibiting IL-23 or the IL-23 receptor, therefore affecting Th17 cells (117-119). Ustekinumab, a highly successful psoriasis treatment, is a monoclonal antibody that binds to p40, a subunit of both IL-23 and IL-12 that causes Th17 cells to die. Guselkumab, tildrakizumab, risankizumab, and mirikizumab are other selective IL-23 blockers with high efficacy in clinical practice and clinical trials. Psoriasis is also being studied with agents that disrupt the JAK/STAT signaling pathways (key intracellular processes in Th17 cytokine generation) (120-122).

Th1. Th1 cell production is enabled by IL-12, a cytokine generated by activated mDCs. It is unclear how IL-12-mediated actions contribute to psoriasis (88). IFN- $\gamma$, IL- 2 , and TNF- $\alpha$ are among the proinflammatory cytokines produced by Th1 cells (123). In non-lesional psoriatic skin, IFN- $\gamma$, the prototypic cytokine produced by these cells, can cause psoriasis-like alterations (124). Of note is that infliximab, an effective anti-TNF medication for psoriasis, can also arrest Th1 cells from producing IFN- $\gamma(125)$.

$C D 8^{+}$T cells. Cytotoxic CD8 T cells that are mostly present in the epidermis of psoriatic skin, produce cytolitic enzymes and play a smaller role in psoriasis than $\mathrm{CD}^{+} \mathrm{T}$ cells via the production of inflammatory cytokines such as IL-17A (126-128). The predominance of Th1/IFN- $\gamma$ and pro-inflammatory cytokines, occurs in the chronic phase $(129,130)$, as opposed to the IL-23/Th17/IL-17 axis that has a major role in the onset of psoriasis inflammation (131). Indeed, the disease is marked by an increase in cytokines from the Th1 pathway (IL-2, IFN- $\gamma$, IL-12, and TNF- $\alpha$ ) (132,133). Furthermore, IFN- $\gamma$, TNF- $\alpha$, IL-18, and IL-12 levels in the peripheral blood are proportionally associated with the severity of psoriasis (36). IFN- $\gamma$, in particular, suppresses keratinocyte death, resulting in hyperproliferation in psoriatic skin (134-136). Notably, clonal restriction of resident memory epidermal T cells seems limited to the $\mathrm{CD}^{+}$compartment (137). As these types of MHC class 
I-restricted antigens are normally presented in CD8 T cells, rather than $\mathrm{CD} 4 \mathrm{~T}$ cells, this finding suggests a relationship between viral or self-antigens in the epidermis and triggering of psoriasis (138).

TRMs. T cells are present in healthy skin. Following exposure to an antigen, naive $\mathrm{T}$ cells evolve into effector $\mathrm{T}$ cells that can act as immunological defense mechanisms. Subsequent to the immune response most of these cells die; however, some survive and differentiate into memory T cells. Although central memory T cells (TCM) traffic through lymphoid tissues, effector memory cells (TEM) circulate through peripheral tissues. TRM T cells are a newly identified subset of memory $\mathrm{T}$ cells that remain in tissues over a long period of time without circulating in the bloodstream, thereby serving as a first line of adaptive cellular defense (139). However, growing evidence suggests that the abnormal activation of these cells may be involved in the pathogenesis of autoimmune and inflammatory disorders, rendering these cells a potentially novel therapeutic target (140). Approximately 20 billion TRMs are present in healthy adult skin (141).

TRMs differ from traditional TCMs and TEMs in terms of transcription, phenotype, and function. They act as alarm sensors or cytotoxic killers in the T-cell zones of secondary lymphoid organs, lymph, and non-lymphoid tissues including the skin $(137,140,142,143)$.

The aim of TRMs is to defend non-lymphatic tissues against viral and bacterial infections. These cells have also been demonstrated to protect against HSV infection, vaccinia pox, lymphocytic choriomeningitis virus (LCMV), influenza, listeriosis, malaria, and various types of cancer (144).

Immunization involves, among other things, training TRMs how to react rapidly to an infection (145). TRMs are prevalent in numerous tissues and provide a more effective in situ response to infectious pathogens compared to TEMs. Granzyme B, which is useful in the prevention of prevent pathogens from spreading at the infection site, is released. TRMs are also capable of stimulating the innate and adaptive responses of the immune system (146-148). TRMs are cells that connect the adaptive and innate immune systems. They also promote protective immune responses for previously encountered tissue as numerous viruses have tissue tropism. However, mounting evidence suggests their involvement in the pathogenesis of autoimmune diseases including psoriasis, vitiligo, autoimmune hepatitis and rheumatoid arthritis (140), in addition to their protective functions.

Depending on the tissue of residency and the nature of the pathogen, TRMs have variable expression of different markers. As a result, they may exist as distinct subsets with phenotypic heterogeneity. $\mathrm{CD}^{+}$cells that express CD103, CD69, and CD49a are optimally characterized TRMs (149).

CD103 ( $\alpha_{\mathrm{E}}$ integrin chain) binds to E-cadherin, thereby fostering retention within epithelial tissues (150). Only CD8 ${ }^{+}$ TRMs express the CD103 marker (integrin E subunit), not $\mathrm{CD}^{+}{ }^{+} \mathrm{TRM}$ cells. Its expression is the most prominent on epidermal $\mathrm{CD}^{+}$and $\mathrm{CD}^{+}{ }^{+} \mathrm{TRM}$ because it allows them to bind to E-cadherin, which is widely expressed by epithelial cells $(143,151,152)$.

CD69 is a T-cell activation marker and is involved in distinguishing $\mathrm{T}$ cells in tissues from those in circulation and it is responsible for the colonization of TRMs in tissues, preventing them from recirculating. CD69 expression mediates early $\mathrm{T}$-cell retention in the skin by blocking sphingosine 1-phosphate receptor 1 (S1PR1)-mediated egress from tissues (153). CD69 expression is preceded, followed by CD103. Specifically, the former marker, i.e., greatly impacts the early attachment of TRMs in tissue, whereas the latter (CD103) is involved in their persistence subsequent to reaching the skin. The absence of these surface molecules induces a reduction in the TRM cell population, but not a total elimination (143).

CD49a (the $\alpha$-subunit of the $\alpha_{1} \beta_{1}$ integrin receptor, also known as very late antigen VLA-1) is another TRM cell marker. CD49a determines a subset of $\mathrm{CD}^{+}$TRMs that are localized in the epidermis. In the skin, CD8 ${ }^{+} \mathrm{CD} 49 \mathrm{a}^{+} \mathrm{TRMs}$, which are abundant in vitiligo, produce perforin, granzyme B, and IFN- $\gamma$, the last of which is a key cytokine in fighting viral infections. In addition, $\mathrm{CD} 8{ }^{+} \mathrm{CD} 49 \mathrm{a}^{+} \mathrm{TRMs}$ acquire high cytotoxic capacity upon IL-15 stimulation $(154,155)$. These cells, on the other hand, do not express high quantities of these cytolytic molecules in the absence of external stimulation, and thus differ from circulating $\mathrm{CD}^{+} \mathrm{T}$ cells (156). Psoriasis is caused by $\mathrm{CD}^{+} \mathrm{CD} 49^{-}$TRMs that generate IL-17 and concentrate in the skin $(154,155)$. TRMs also expresses the surface proteins that suppresses T-cell activity, such as program cell death protein-1 (PD-1) and T-cell immunoglobulin mucin receptor 3 (TIM3). The expression of these proteins occurs in inflamed tissues. In such situations, TRMs exert an anti-inflammatory effect, indicating the ambiguous character of these cells $(157,158)$.

In psoriasis, Th1 and Th17 phenotype $\mathrm{CD}^{+} \mathrm{T}$ cells are considered the most pathogenic T-cell subpopulations. A clearer understanding has been gained of the role of LL-37 (an antimicrobial peptide formed from keratinocytes) and ADAMTSL5 (a protein produced by melanocytes) in the etiology of psoriasis. The proteins listed above are known as autoantigens. LL-37 is also recognized as an autoantigen by CD4 $\mathrm{T}$ cells, and it correlates with the Psoriasis Area Severity Index (PASI) $(52,66)$. In psoriatic epidermis, CD8 ${ }^{+}$ T lymphocytes with TRM phenotype are numerous, but $\mathrm{CD}^{+}$ TRMs preferentially occupy the dermis. The differences in colonization are caused by the presence of CD69, which inhibits the sphingosine-1-phosphate receptor (S1P1), which normally allows lymphatic entrance. A considerable proportion of skin TRMs also expresses CD103, the $\alpha_{E} \beta_{7}$ integrin chain that interacts with E-cadherin expressed by keratinocytic cells. TGF- $\beta$ through TGF-RII is the signal essential for their survival (145). Hair follicles, through IL-15 and IL-7 production, are also important in their recruitment (159). In addition to cytokines, lipids found in the skin are necessary for the maintenance of TRMs.

TRMs have been identified in recurrent psoriasis sites in unaltered and cured skin, indicating their involvement in the local memory of the disease (160). Memory T-cell recirculation between the skin and circulation is a recently identified immunological mechanism that plays a key role in the onset of the psoriasiform response (161-163). The pathogenicity of TRMs is determined by their ability to generate the pro-inflammatory cytokines IL-17 and IL-22, which are important in this process $(158,162)$. 
The experiment of Boyman et al (164) was the first to show the significance of resident cutaneous $\mathrm{T}$ lymphocytes in psoriasis. Authors of that study used immunodeficient mice (AGR129 mice, which lack type I and II interferon receptors, as well as the recombination activating gene 2) to implant unchanged human psoriatic skin. Within 8 weeks, the reproduction of resident human $\mathrm{T}$ lymphocytes and the establishment of psoriatic lesions were detected. They were mostly found in the epidermis and dermal-epidermal junction, and they had the $\mathrm{CD} 8^{+}$phenotype with TNF- $\alpha$ susceptibility (164).

$\mathrm{CD}^{+} \mathrm{T}$ cells, which produce pro-inflammatory cytokines such as IL-17A, IL-22, and IFN- $\gamma$, are thought to be the predominant pathogenic T-cell subpopulation, but $\mathrm{CD} 8^{+}$ memory $\mathrm{T}$ cells, which are found in healthy skin, have a similar pro-inflammatory cytokine profile. These cells can identify peptide antigens presented on MHC class I molecules, including HLA-Cw6, and are abundant in the psoriatic epidermis (162). On the murine AGR model of psoriasis, blocking 1-integrin arrested $\mathrm{T}$ cells from entering the epidermis, which reduces disease eruptions (126). Di Meglio et al (162) demonstrated that an increase in epidermal $\mathrm{CD}^{+}$cells causes keratinocyte hyperproliferation as well as papillomatosis (an increase in $\mathrm{CD} 8^{+}$cells that corresponds to the intensity of Ki67 staining in keratinocytes) (162). Psoriasis-related cytokines are produced by $\mathrm{CD} 8^{+} \mathrm{T}$ lymphocytes isolated from psoriasis patients. These cytokines remain in the skin after treatment, as TRMs and LL-37-specific CD8 ${ }^{+} \mathrm{T}$ cells that express integrin $\alpha_{1} \beta_{1}(162)$.

The optimal treatment time required to totally silence TRMs and ensure that lesions do not recur at the same site remains to be determined (165). As a result, psoriatic lesions reappear more frequently in previously affected skin areas, and pathogenic TRMs exposed to IL-17A and IL-22 accumulate in resolved lesions $(137,166)$. Sérézal et al $(167)$ investigated tissue responses after T-cell stimulation in healthy and psoriatic lesions. An increase in the number of epidermal IL-17 and IL-22 (producing skin-resident T CCR6 ${ }^{+}$cells) may be a genetically predisposed response to microbial stimulation in never-lesional skin in psoriasis patients. As a result, IFN- $\gamma$ production increases, and keratinocytes that produce INF- $\alpha$ are stimulated, causing psoriatic inflammation.

Psoriasis plaques, on the other hand, revealed IL-17-induced response patterns, indicating a relapse. The proportional amount of induced IFN- $\gamma$, IL-10e, and IL-17A was associated with the time it took for patients to relapse after stopping treatment (167).

Biopsies from psoriatic lesions were examined in a study by Kurihara et al (151). The number of $\mathrm{CD} 8^{+} \mathrm{CD} 103^{+} \mathrm{TRMs}$ in the epidermis was shown to be linked with epidermal thickness $(\mathrm{P}=0.016)$, suggesting an important role in the development of psoriatic lesions (151). The majority of TRMs were $\mathrm{CD} 8{ }^{+} \mathrm{CD} 69^{+} \mathrm{T}$ cells that expressed skin colonization antigens, with a modest number of $\mathrm{CD}^{+} \mathrm{CD}^{+} 03^{+} \mathrm{TRM}$. IFN- $\gamma$, IL-17A, and IL-22 were generated by some of the $\mathrm{CD} 8^{+} \mathrm{CD} 103^{+}$ $\mathrm{T}$ cells. Furthermore, $\mathrm{CD} 8^{+} \mathrm{CD} 103^{+} \mathrm{TRMs}$ produced more IL-17A than $\mathrm{CD}^{+} \mathrm{CD} 103^{-}$and effector cells $\mathrm{CD}^{+} \mathrm{CD} 103^{+}$or $\mathrm{CD} 4^{+} \mathrm{CD} 103^{+}$. The number of $\mathrm{CD} 8^{+} \mathrm{CD} 103^{+} \mathrm{IL}_{-}-17 \mathrm{~A}^{+} \mathrm{TRMs}$ was higher in individuals who received biological or systemic therapy (151). TRMs, on the other hand, expressed less
CD103 in the dermis of psoriatic plaques, as demonstrated by Cheuk et al (137). Epidermal TRMs expressing CCR6 collaborate with CCL20-expressing keratinocytes in the early stages of psoriatic inflammation, in the skin where lesions are absent $(166,168)$.

Vo et al (168) investigated the phenotypic characteristics of TRMs in non-lesional, lesional, and healthy skin. When compared to the skin of healthy subjects, an immunofluorescence study revealed that $\mathrm{CD} 103^{+} \mathrm{CD}^{+}{ }^{+} \mathrm{TRMs}$ were prevalent in both non-lesional and lesional epidermis. Furthermore, individuals with a longer disease duration produced more IL-17A (168).

Diani et al (169) investigated the phenotype of circulating T lymphocytes in psoriasis patients using gene expression analysis in psoriatic skin. The percentage of $\mathrm{CCR} 6^{+} \mathrm{CD} 4^{+} \mathrm{TEMs}$ and TEMs in the blood was found to be positively connected with the severity of skin lesions and inflammation (CRP, C-reactive protein), while the percentage of $\mathrm{CXCR} 3^{+} \mathrm{CD} 4^{+} \mathrm{TEMs}$ was found to be negatively correlated. Furthermore, the severity of psoriasis was negatively correlated with $\mathrm{CLA}^{+} \mathrm{CD} 4^{+} \mathrm{TCMs}$ expressing $\mathrm{CCR}^{+}$or $\mathrm{CCR} 4^{+} \mathrm{CXCR} 3^{+}$. CLA expression has been linked to the recruitment of $\mathrm{CD}^{+} \mathrm{T}$ cells into the skin, particularly when expressed on TCMs, especially $\mathrm{CD} 4^{+} \mathrm{TCMs}$ with the CCR4 $4^{+}$and $\mathrm{CCR} 6^{+}$phenotype $(52,169)$. In a previous study, Bosè et al (170) demonstrated that the inhibition of the CCR7/CCL19 axis was required for psoriasis remission produced by TNF inhibitors (161). In psoriasis, circulating CCR $4^{+} \mathrm{CD} 4^{+} \mathrm{T}$ cells have a substantial correlation with the PASI, while $\mathrm{CCR} 5^{+} \mathrm{CD}^{+} \mathrm{T}$ cells have a strong negative correlation (170). Systemic inflammation (CRP) and the severity of skin lesions are both strongly correlated with a subpopulation of $\mathrm{T}$ effector $\mathrm{CCR} 4{ }^{+} \mathrm{CD} 8{ }^{+} \mathrm{CD} 103^{+}$cells $(171,172)$. The fraction of IL-17 secreting CD4 $4^{+} \mathrm{T}$ lymphocytes, and likely $\gamma \delta$ T-lymphocytes, was also found to play a role in the creation of a self-sustaining inflammatory loop (169).

TRM suppression is necessary for complete remission of the disease. TRMs, however, have a long lifespan and are resistant to both harmful agents and apoptosis. This explains the reason for frequent psoriasis relapses in the same area. TRMs are capable of generating IL-17A even after the clinical lesions have resolved, and effective therapy merely reduces their activity $(161,165)$. CD8 ${ }^{+}$TRMs also accumulate in untreated psoriasis localizations, which is probably related to duration of the disease $(140,171)$. The explanation of memory cell lifespan is a fascinating field of study. One of the reasons is its apoptosis resistance. $\mathrm{CD} 8^{+}\left(\alpha_{\mathrm{E}} \beta_{7}\right)$ is a heterodimeric marker compound, comprised of $\mathrm{CD} 103$ and beta7 subunits, that plays a vital function in the stability of $\mathrm{CD} 8^{+} \mathrm{TRMs}$ by elevating the expression of the anti-apoptotic Bcl-2 molecule $(143,151)$. TRMs, on the other hand, can produce granzyme B (serine protease), which can cause cell death (158). Furthermore, IL-15 is thought to play a role in TRM cell survival (173).

Of note is that the effector $\mathrm{T}$ cells generate adenosine triphosphate (ATP) using glycolysis energy, which is less efficient but faster. Endogenously produced fatty acids, glucose catabolism, and oxidative phosphorylation are used by TCMs on the other hand, to support their long-term survival and function $(174,175)$. TCMs use extracellular glucose from the blood to generate fatty acids in the endoplasmic reticulum, using lysosomal acid lipase, which is required for the breakdown 
of cholesteryl esters and triglycerides in LDL molecules to cholesterol and free fatty acids (FFA). They can be long-lived and react rapidly to antigen owing to such mechanisms (174). Cui et al also revealed that IL-7, a cytokine important for TCM differentiation and survival, increased glycerol transport and triacylglycerol synthesis by upregulating the gene expression of the glycerol channel aquaporin 9, thereby providing substrates for mitochondria via fatty acid oxidation (FAO) $(174,176)$.

However, the metabolic characteristics of TRMs are currently unknown due to a lack of accurate data. CD8 $8^{+}$ TRMs, on the other hand, are known to establish a transcriptional pathway that includes the overexpression of FABP4 (adipocyte-FABP), FABP5 (epidermal-FABP), CD36 (lipid scavenger receptor), and lipoprotein lipase (cleaves triglycerides to yield FFA and diacylglycerol). In naive T cells, TCMs, or effector memory cells, such activity of genes responsible for the action of these molecules is not found (174).

Pan and Kupper (174) found that mouse CD8 ${ }^{+}$TRMs produced by cutaneous viral infection have a different expression level of genes encoding proteins that mediate intracellular lipid uptake and transport, such as fatty acid-binding protein-FABP4 (adipocyte-FABP) and FABP5 (epidermal-FABP). These are substances that aid in the acquisition and metabolism of exogenous FFAs (174). CD8 ${ }^{+}$TRMs upregulated the gene expression of FABP4/FABP5 in a peroxisome proliferator-activated receptor (PPAR)- $\gamma$-dependent manner $(174,177)$. T-specific deficit of these molecules has been found to impair $\mathrm{CD}^{+}$TRM uptake of exogenous FFA, reducing their long-term survival in vivo, but has no impact on TCM survival in lymph nodes. Furthermore, $\mathrm{CD} 8^{+} \mathrm{TRM}$ skin cells missing FABP4/FABP5 were less effective in protecting mice against cutaneous viral infection (177). This remains to be determined in psoriasis patients as compared to healthy subjects.

In the presence of exogenous FFA, $\mathrm{CD}^{+}$TRMs revealed increased oxidative metabolism of mitochondria in normal and psoriatic skin in vitro. These findings suggest that FABP4 and FABP5 are important for CD8 ${ }^{+}$TRM maintenance, lifespan, and function, and that $\mathrm{CD} 8^{+}$TRMs rely on exogenous FFA and their oxidative metabolism to survive in tissue. FABP4 and FABP5 deficiency has been demonstrated to have no effect on $\mathrm{CD}^{+} \mathrm{T}$-cell proliferation or skin recruitment, but they are required for their long-term survival in the skin (177). Blocking PPAR- $\gamma$ functions may pave the way for the development of psoriatic lesion therapeutic strategies.

Psoriatic inflammation is exacerbated by oxidative stress. The redox status of $\mathrm{CD}^{+}$TRMs and its connection with IL-17 response were studied by Esmaeili et al (178). The increased intracellular ROS production in $\mathrm{CD}^{+}$memory $\mathrm{T}$ cells in patients with psoriasis reduced the catalase gene expression relative to healthy cells, but there were no differences in the intracellular glutathione levels or plasma total antioxidant capacity. The above diseases, however, seemed to have no impact on the IL-17 response in memory T cells (178).

Regulatory T cells. Finally, regulatory T-cell (Treg) dysfunction, which is primarily involved in maintaining tolerance and avoiding autoimmune diseases, is a key factor in the pathogenesis of psoriasis (179). These Tregs had a decreased function in counterbalancing pathogenic $\mathrm{T}$ cells during psoriasis. Notably, Foxp $3^{+}$Tregs from psoriasis patients can more quickly develop into pathogenic Th17 cells than other Foxp $^{+}$Tregs. IL- $17 \mathrm{~A}^{+} / \mathrm{Foxp3}^{+} / \mathrm{CD}^{+}$triple-positive cells can be found in the skin lesions on a regular basis and can be utilized to determine the severity of psoriasis. Understanding Treg features in psoriasis can therefore aid in the development of immunotherapies to treat disease.

\section{Conclusions}

In conclusion, psoriasis is a chronic inflammatory skin disorder that is mostly genetically determined and is associated with a wide range of medical and psychological comorbidities. Recent findings on the etiopathogenesis of psoriasis as they relate to genetic factor, AMPs, the IL23/Th17/IL17 axis, TRMs and Tregs were assessed in this review. New therapies were also mentioned.

The pathophysiology of psoriasis is still being researched. To improve the quality of life of psoriatic patients, the choice of available treatments is now increasing. Advances in understanding of the pathophysiology of the disease will almost certainly lead to the finding of new therapeutic treatments and improved patient outcomes.

\section{Acknowledgements}

Not applicable.

\section{Funding}

Publishing funds were supported by the Association of Dermatologists from Moldova.

\section{Availability of data and materials}

All information contained in this review is documented by relevant references.

\section{Authors' contributions}

DEB, EAP and AIA contributed to the study design, participated in the entire review process, and prepared the manuscript. $\mathrm{CC}, \mathrm{RD}, \mathrm{GB}, \mathrm{AD}$ and $\mathrm{MZ}$ contributed to collecting the relevant literature, data analysis, and critical interpretation. ACN, IB, CMB, NA, MPT, AD and DCB conceived the review and modified the manuscript. All authors read and approved the final version of the manuscript. Data authentication is not applicable.

\section{Ethics approval and consent to participate}

Not applicable.

\section{Patient consent for publication}

Not applicable.

\section{Competing interests}

All the authors declare that they have no competing interests. 


\section{Authors' information}

Author GB is a medical student at 'Grigore T. Popa' University of Medicine and Pharmacy Iasi, Romania.

\section{References}

1. Tokuyama M and Mabuchi T: New treatment addressing the pathogenesis of psoriasis. Int J Mol Sci 21: 7488, 2020.

2. Griffiths CE and Barker JN: Pathogenesis and clinical features of psoriasis. Lancet 370: 263-271, 2007.

3. Nestle FO, Kaplan DH and Barker J: Psoriasis. N Engl J Med 361: 496-509, 2009

4. Parisi R, Symmons DPM, Griffiths CE and Ashcroft DM; Identification and Management of Psoriasis and Associated ComorbidiTy (IMPACT) project team: Global epidemiology of psoriasis: A systematic review of incidence and prevalence. J Invest Dermatol 133: 377-385, 2013.

5. Rachakonda TD, Schupp CW and Armstrong AW: Psoriasis prevalence among adults in the United States. J Am Acad Dermatol 70: 512-516, 2014.

6. Parisi R, Iskandar IYK, Kontopantelis E, Augustin M, Griffiths CEM and Ashcroft DM; Global Psoriasis Atlas: National, regional, and worldwide epidemiology of psoriasis: Systematic analysis and modelling study. BMJ 369: m1590, 2020

7. Michalek IM, Loring B and John SM: A systematic review of worldwide epidemiology of psoriasis. J Eur Acad Dermatol Venereol 31: 205-212, 2017

8. Dand N, Mahil SK, Capon F, Smith CH, Simpson MA and Barker JN: Psoriasis and Genetics. Acta Derm Venereol 100: adv00030, 2020

9. O'Rielly DD, Jani M, Rahman P and Elder JT: The genetics of psoriasis and psoriatic arthritis. J Rheumatol (Suppl 95): 46-50, 2019.

10. Weiss G, Shemer A and Trau H: The Koebner phenomenon: Review of the literature. J Eur Acad Dermatol Venereol 16: 241-248, 2002

11. Malhotra SK and Mehta V: Role of stressful life events in induction or exacerbation of psoriasis and chronic urticaria. Indian J Dermatol Venereol Leprol 74: 594-599, 2008.

12. Basavaraj KH, Ashok NM, Rashmi R and Praveen TK: The role of drugs in the induction and/or exacerbation of psoriasis. Int J Dermatol 49: 1351-1361, 2010.

13. Fry L and Baker BS: Triggering psoriasis: The role of infections and medications. Clin Dermatol 25: 606-615, 2007.

14. Higgins E: Alcohol, smoking and psoriasis. Clin Exp Dermatol 25: 107-110, 2000.

15. Armstrong AW, Harskamp CT and Armstrong EJ: The association between psoriasis and obesity: A systematic review and metaanalysis of observational studies. Nutr Diabetes 2: e54, 2012.

16. Balato N, Di Costanzo L, Patruno C, Patrì A and Ayala F: Effect of weather and environmental factors on the clinical course of psoriasis. Occup Environ Med 70: 600, 2013.

17. López-Estebaranz JL, Sánchez-Carazo JL and Sulleiro S: Effect of a family history of psoriasis and age on comorbidities and quality of life in patients with moderate to severe psoriasis: Results from the ARIZONA study. J Dermatol 43: 395-401, 2016

18. Duffy DL, Spelman LS and Martin NG: Psoriasis in Australian twins. J Am Acad Dermatol 29: 428-434, 1993.

19. Trembath RC, Clough RL, Rosbotham JL, Jones AB, Camp RD, Frodsham A, Browne J, Barber R, Terwilliger J, Lathrop GM and Barker JN: Identification of a major susceptibility locus on chromosome $6 \mathrm{p}$ and evidence for further disease loci revealed by a two stage genome-wide search in psoriasis. Hum Mol Genet 6: 813-820, 1997.

20. Sagoo GS, Tazi-Ahnini R, Barker JWN, Elder JT, Nair RP, Samuelsson L, Traupe H, Trembath RC, Robinson DA and Iles MM: Meta-analysis of genome-wide studies of psoriasis susceptibility reveals linkage to chromosomes $6 \mathrm{p} 21$ and 4q28-q31 in Caucasian and Chinese Hans population. J Invest Dermatol 122: 1401-1405, 2004

21. Chen L and Tsai TF: HLA-Cw6 and psoriasis. Br J Dermatol 178: 854-862, 2018

22. Umapathy S, Pawar A, Mitra R, Khuperkar D, Devaraj JP, Ghosh K and Khopkar U: Hla-a and Hla-B alleles associated in psoriasis patients from Mumbai, Western India. Indian J Dermatol 56: 497-500, 2011.
23. Nair RP, Duffin KC, Helms C, Ding J, Stuart PE, Goldgar D, Gudjonsson JE, Li Y, Tejasvi T, Feng BJ, et al: Genome-wide scan reveals association of psoriasis with IL-23 and NF-kappaB pathways. Nat Genet 41: 199-204, 2009.

24. Cargill M, Schrodi SJ, Chang M, Garcia VE, Brandon R, Callis KP, Matsunami N, Ardlie KG, Civello D, Catanese JJ, et al: A large-scale genetic association study confirms IL12B and leads to the identification of IL23R as psoriasis-risk genes. Am J Hum Genet 80: 273-290, 2007.

25. Garcia VE, Chang M, Brandon R, Li Y, Matsunami N, Callis-Duffin KP, Civello D, Rowland CM, Bui N, Catanese JJ, et al: Detailed genetic characterization of the interleukin-23 receptor in psoriasis. Genes Immun 9: 546-555, 2008.

26. Hasegawa H, Mizoguchi I, Chiba Y, Ohashi M, Xu M and Yoshimoto T: Expanding diversity in molecular structures and functions of the IL-6/IL-12 heterodimeric cytokine Family. Front Immunol 7: 479, 2016.

27. Onoufriadis A, Simpson MA, Pink AE, Di Meglio P, Smith CH, Pullabhatla V, Knight J, Spain SL, Nestle FO, Burden AD, et al: Mutations in IL36RN/IL1F5 are associated with the severe episodic inflammatory skin disease known as generalized pustular psoriasis. Am J Hum Genet 89: 432-437, 2011.

28. Cullen G, Kroshinsky D, Cheifetz AS and Korzenik JR: Psoriasis associated with anti-tumour necrosis factor therapy in inflammatory bowel disease: A new series and a review of 120 cases from the literature. Aliment Pharmacol Ther 34: 1318-1327, 2011.

29. Pugliese D, Guidi L, Ferraro PM, Marzo M, Felice C, Celleno L, Landi R, Andrisani G, Pizzolante F, De Vitis I, et al: Paradoxical psoriasis in a large cohort of patients with inflammatory bowel disease receiving treatment with anti-TNF alpha: 5-year follow-up study. Aliment Pharmacol Ther 42: 880-888, 2015.

30. Eickstaedt JB, Killpack L, Tung J, Davis D, Hand JL and Tollefson MM: Psoriasis and psoriasiform eruptions in pediatric patients with inflammatory bowel disease treated with Anti-tumor necrosis factor alpha agents. Pediatr Dermatol 34: 253-260, 2017.

31. Famenini S and Wu JJ: Infliximab-induced psoriasis in treatment of Crohn's disease-associated ankylosing spondylitis: Case report and review of 142 cases. J Drugs Dermatol 12: 939-943, 2013.

32. Filoni A, Vestita M, Congedo M, Giudice G, Tafuri S and Bonamonte D: Association between psoriasis and vitamin D: Duration of disease correlates with decreased vitamin D serum levels: An observational case-control study. Medicine (Baltimore) 97: e11185, 2018.

33. Orgaz-Molina J, Buendía-Eisman A, Arrabal-Polo MA, Ruiz JC and Arias-Santiago S: Deficiency of serum concentration of 25-hydroxyvitamin D in psoriatic patients: A case-control study. J Am Acad Dermatol 67: 931-938, 2012

34. Porumb-Andrese E, Vâtă D, Postolică R, Stătescu L, Stătescu C, Grăjdeanu AI, Pătraşcu AI, Popescu IA and Solovastru LG: Association between personality type, affective distress profile and quality of life in patients with psoriasis vs. patients with cardiovascular disease. Exp Ther Med 18: 4967-4973, 2019.

35. Cai Y, Fleming C and Yan J: New insights of T cells in the pathogenesis of psoriasis. Cell Mol Immunol 9: 302-309, 2012.

36. Coimbra S, Figueiredo A, Castro E, Rocha-Pereira P and Santos-Silva A: The roles of cells and cytokines in the pathogenesis of psoriasis. Int J Dermatol 51: 389-395, 2012.

37. Boehncke WH: Etiology and pathogenesis of psoriasis. Rheum Dis Clin North Am 41: 665-675, 2015.

38. Lai Y and Gallo RL: AMPed up immunity: How antimicrobial peptides have multiple roles in immune defense. Trends Immunol 30: 131-141, 2009.

39. Ogawa E, Sato Y, Minagawa A and Okuyama R: Pathogenesis of psoriasis and development of treatment. J Dermatol 45: 264-272, 2018.

40. Rendon A and Schäkel K: Psoriasis pathogenesis and treatment. Int J Mol Sci 20: 1475, 2019.

41. Eckert RL, Broome AM, Ruse M, Robinson N, Ryan D and Lee K: S100 proteins in the epidermis. J Invest Dermatol 123: 23-33, 2004

42. Büchau AS and Gallo RL: Innate immunity and antimicrobial defense systems in psoriasis. Clin Dermatol 25: 616-624, 2007.

43. Liang SC, Tan XY, Luxenberg DP, Karim R, Dunussi-Joannopoulos K, Collins M and Fouser LA: Interleukin (IL)-22 and IL-17 are coexpressed by Th17 cells and cooperatively enhance expression of antimicrobial peptides. J Exp Med 203: 2271-2279, 2006. 
44. Jinquan T, Vorum H, Larsen CG, Madsen P, Rasmussen HH, Gesser B, Etzerodt M, Honoré B, Celis JE and ThestrupPedersen K: Psoriasin: A novel chemotactic protein. J Invest Dermatol 107: 5-10, 1996.

45. Harder J and Schröder JM: Psoriatic scales: A promising source for the isolation of human skin-derived antimicrobial proteins. J Leukoc Biol 77: 476-486, 2005.

46. Morizane S and Gallo RL: Antimicrobial peptides in the pathogenesis of psoriasis. J Dermatol 39: 225-230, 2012.

47. Frohm M, Agerberth B, Ahangari G, Stâhle-Bäckdahl M, Lidén S, Wigzell $\mathrm{H}$ and Gudmundsson G: The expression of the gene coding for the antibacterial peptide LL-37 is induced in human keratinocytes during inflammatory disorders. J Biol Chem 272: 15258-15263, 1997.

48. Lande R, Gregorio J, Facchinetti V, Chatterjee B, Wang YH, Homey B, Cao W, Wang YH, Su B, Nestle FO, et al: Plasmacytoid dendritic cells sense self-DNA coupled with antimicrobial peptide. Nature 449: 564-569, 2007.

49. Morizane S, Yamasaki K, Mühleisen B, Kotol PF, Murakami M, Aoyama Y, Iwatsuki K, Hata T and Gallo RL: Cathelicidin antimicrobial peptide LL-37 in psoriasis enables keratinocyte reactivity against TLR9 Ligands. J Invest Dermatol 132: 135-143, 2012.

50. Hänsel A, Günther C, Ingwersen J, Starke J, Schmitz M, Bachmann M, Meurer M, Rieber EP and Schäkel K: Human slan (6-sulfo LacNAc) dendritic cells are inflammatory dermal dendritic cells in psoriasis and drive strong Th17/Th1 T-cell responses. J Allergy Clin Immunol 127: 787-794.e1-e9, 2011.

51. Mabuchi $\mathrm{T}$ and Hirayama $\mathrm{N}$ : Binding affinity and interaction of LL-37 with HLA-C*06:02 in psoriasis. J Invest Dermatol 136 1901-1903, 2016.

52. Arakawa A, Siewert K, Stöhr J, Besgen P, Kim SM, Rühl G, Nickel J, Vollmer S, Thomas P, Krebs S, et al: Melanocyte antigen triggers autoimmunity in human psoriasis. J Exp Med 212: 2203-2212, 2015.

53. Krueger JG: An autoimmune 'attack' on melanocytes triggers psoriasis and cellular hyperplasia. J Exp Med 212: 2186-2186, 2015.

54. Nishimoto S, Kotani H, Tsuruta S, Shimizu N, Ito M, Shichita T, Morita R, Takahashi H, Amagai M and Yoshimura A: Th17 cells carrying TCR recognizing epidermal autoantigen induce psoriasis-like skin inflammation. J Immunol 191: 3065-3072, 2013.

55. Chiricozzi A, Romanelli P, Volpe E, Borsellino G and Romanelli M: Scanning the immunopathogenesis of psoriasis. Int J Mol Sci 19: E179, 2018

56. Fuentes-Duculan J, Bonifacio KM, Hawkes JE, Kunjravia N, Cueto I, Li X, Gonzalez J, Garcet S and Krueger JG: Autoantigens ADAMTSL5 and LL37 are significantly upregulated in active Psoriasis and localized with keratinocytes, dendritic cells and other leukocytes. Exp Dermatol 26: 1075-1082, 2017.

57. Bonifacio KM, Kunjravia N, Krueger JG and Duculan JF: Cutaneous expression of A Disintegrin-like and Metalloprotease domain containing thrombospondin type 1 motif-like 5 (ADAMTSL5) in psoriasis goes beyond Melanocytes. J Pigment Disord 3: 244, 2016

58. Liu YJ: IPC: Professional type 1 interferon-producing cells and plasmacytoid dendritic cell precursors. Annu Rev Immunol 23: 275-306, 2005

59. Benhadou F, Mintoff D and Del Marmol V: Psoriasis: Keratinocytes or immune cells-which is the trigger? Dermatology 235: 91-100, 2019.

60. Nestle FO, Conrad C, Tun-Kyi A, Homey B, Gombert M, Boyman O, Burg G, Liu YJ and Gilliet M: Plasmacytoid predendritic cells initiate psoriasis through interferon-alpha production. J Exp Med 202: 135-143, 2005.

61. van der Fits L, van der Wel LI, Laman JD, Prens EP and Verschuren MCM: In psoriasis lesional skin the type I interferon signaling pathway is activated, whereas interferon-alpha sensitivity is unaltered. J Invest Dermatol 122: 51-60, 2004.

62. Gilliet M, Conrad C, Geiges M, Cozzio A, Thürlimann W, Burg G, Nestle FO and Dummer R: Psoriasis triggered by toll-like receptor 7 agonist imiquimod in the presence of dermal plasmacytoid dendritic cell precursors. Arch Dermatol 140: 1490-1495, 2004.

63. Vinter H, Iversen L, Steiniche T, Kragballe K and Johansen C: Aldara ${ }^{\circledR}$-induced skin inflammation: Studies of patients with psoriasis. Br J Dermatol 172: 345-353, 2015.

64. Takeda K, Kaisho T and Akira S: Toll-like receptors. Annu Rev Immunol 21: 335-376, 2003.
65. Honda K, Ohba Y, Yanai H, Negishi H, Mizutani T, Takaoka A Taya $\mathrm{C}$ and Taniguchi T: Spatiotemporal regulation of MyD88-IRF-7 signalling for robust type-I interferon induction. Nature 434: 1035-1040, 2005.

66. Lande R, Botti E, Jandus C, Dojcinovic D, Fanelli G, Conrad C, Chamilos G, Feldmeyer L, Marinari B, Chon S, et al: The antimicrobial peptide LL37 is a T-cell autoantigen in psoriasis. Nat Commun 5: 5621, 2014

67. Farkas A and Kemény L: Interferon- $\alpha$ in the generation of monocyte-derived dendritic cells: Recent advances and implications for dermatology. Br J Dermatol 165: 247-254, 2011.

68. Lowes MA, Chamian F, Abello MV, Fuentes-Duculan J, Lin SL, Nussbaum R, Novitskaya I, Carbonaro H, Cardinale I, Kikuchi T, et al: Increase in TNF-alpha and inducible nitric oxide synthase-expressing dendritic cells in psoriasis and reduction with efalizumab (anti-CD11a). Proc Natl Acad Sci USA 102: 19057-19062, 2005.

69. Zaba LC, Cardinale I, Gilleaudeau P, Sullivan-Whalen M, Suárez-Fariñas M, Fuentes-Duculan J, Novitskaya I, Khatcherian A, Bluth MJ, Lowes MA and Krueger JG: Amelioration of epidermal hyperplasia by TNF inhibition is associated with reduced Th17 responses. J Exp Med 204: 3183-3194, 2007.

70. Zaba LC, Krueger JG and Lowes MA: Resident and 'inflammatory' dendritic cells in human skin. J Invest Dermatol 129: 302-308, 2009.

71. Martini E, Wikén M, Cheuk S, Gallais Sérézal I, Baharom F, Ståhle M, Smed-Sörensen A and Eidsmo L: Dynamic changes in resident and infiltrating epidermal dendritic cells in active and resolved psoriasis. J Invest Dermatol 137: 865-873, 2017.

72. McKenzie BS, Kastelein RA and Cua DJ: Understanding the IL-23-IL-17 immune pathway. Trends Immunol 27: 17-23, 2006.

73. Wang F, Lee E, Lowes MA, Haider AS, Fuentes-Duculan J, Abello MV, Chamian F, Cardinale I and Krueger JG: Prominent production of IL-20 by CD68+/CD11c+ myeloid-derived cells in psoriasis: Gene regulation and cellular effects. J Invest Dermatol 126: 1590-1599, 2006.

74. Nickoloff BJ: The cytokine network in psoriasis. Arch Dermatol 127: 871-884, 1991.

75. Reich K, Nestle FO, Papp K, Ortonne JP, Evans R, Guzzo C, Li S, Dooley LT and Griffiths CE; EXPRESS study investigators: Infliximab induction and maintenance therapy for moderate-to-severe psoriasis: A phase III, multicentre, double-blind trial. Lancet 366: 1367-1374, 2005.

76. Yao Y, Richman L, Morehouse C, de los Reyes M, Higgs BW, Boutrin A, White B, Coyle A, Krueger J, Kiener PA and Jallal B: Type I interferon: Potential therapeutic target for psoriasis? PLoS One 3: e2737, 2008.

77. Funk J, Langeland T, Schrumpf E and Hanssen LE: Psoriasis induced by interferon-alpha. Br J Dermatol 125: 463-465, 1991.

78. Ketikoglou I, Karatapanis S, Elefsiniotis I, Kafiri G and Moulakakis A: Extensive psoriasis induced by pegylated interferon alpha-2b treatment for chronic hepatitis B. Eur J Dermatol 15: 107-109, 2005

79. Patel U, Mark NM, Machler BC and Levine VJ: Imiquimod 5\% cream induced psoriasis: A case report, summary of the literature and mechanism. Br J Dermatol 164: 670-672, 2011.

80. van der Fits L, Mourits S, Voerman JS, Kant M, Boon L, Laman JD, Cornelissen F, Mus AM, Florencia E, Prens EP and Lubberts E: Imiquimod-induced psoriasis-like skin inflammation in mice is mediated via the IL-23/IL-17 axis. J Immunol 182: 5836-5845, 2009

81. Hida S, Ogasawara K, Sato K, Abe M, Takayanagi H, Yokochi T, Sato T, Hirose S, Shirai T, Taki S and Taniguchi T: CD8(+) T cell-mediated skin disease in mice lacking IRF-2, the transcriptional attenuator of interferon-alpha/beta signaling. Immunity 13 : 643-655, 2000

82. Tracey D, Klareskog L, Sasso EH, Salfeld JG and Tak PP: Tumor necrosis factor antagonist mechanisms of action: A comprehensive review. Pharmacol Ther 117: 244-279, 2008.

83. Uyemura K, Yamamura M, Fivenson DF, Modlin RL and Nickoloff BJ: The cytokine network in lesional and lesion-free psoriatic skin is characterized by a T-helper type 1 cell-mediated response. J Invest Dermatol 101: 701-705, 1993.

84. Mocanu M, Toader MP, Rezus E and Taranu T: Aspects concerning patient adherence to anti-TNF $\alpha$ therapy in psoriasis: A decade of clinical experience. Exp Ther Med 18: 4987-4992, 2019. 
85. Menter A, Tyring SK, Gordon K, Kimball AB, Leonardi CL Langley RG, Strober BE, Kaul M, Gu Y, Okun M and Papp K: Adalimumab therapy for moderate to severe psoriasis: A randomized, controlled phase III trial. J Am Acad Dermatol 58: 106-115, 2008.

86.Papp KA, Tyring S, Lahfa M, Prinz J, Griffiths CE, Nakanishi AM, Zitnik R, van de Kerkhof PCM and Melvin L; Etanercept psoriasis study group: A global phase III randomized controlled trial of etanercept in psoriasis: Safety, efficacy, and effect of dose reduction. Br J Dermatol 152: 1304-1312, 2005.

87. Blauvelt A, Reich K, Lebwohl M, Burge D, Arendt C, Peterson L, Drew J, Rolleri R and Gottlieb AB: Certolizumab pegol for the treatment of patients with moderate-to-severe chronic plaque psoriasis: Pooled analysis of week 16 data from three randomized controlled trials. J Eur Acad Dermatol Venereol 33: 546-552, 2019.

88. Lee E, Trepicchio WL, Oestreicher JL, Pittman D, Wang F, Chamian F, Dhodapkar M and Krueger JG: Increased expression of interleukin 23 p19 and p40 in lesional skin of patients with psoriasis vulgaris. J Exp Med 199: 125-130, 2004

89. Haider AS, Lowes MA, Suárez-Fariñas M, Zaba LC, Cardinale I, Khatcherian A, Novitskaya I, Wittkowski KM and Krueger JG: Identification of cellular pathways of 'type 1,' Th17 T cells, and TNF- and inducible nitric oxide synthase-producing dendritic cells in autoimmune inflammation through pharmacogenomic study of cyclosporine A in psoriasis. J Immunol 180: 1913-1920, 2008.

90. Mahil SK, Capon F and Barker JN: Update on psoriasis immunopathogenesis and targeted immunotherapy. Semin Immunopathol 38: 11-27, 2016.

91. Grechin C, Solovăstru LG, Vâță D, Pătrașcu AI, Grăjdeanu AI and Porumb-Andrese E: Inflammatory marker alteration in response to systemic therapies in psoriasis. Exp Ther Med 20: 42-46, 2020

92. Chan JR, Blumenschein W, Murphy E, Diveu C, Wiekowski M, Abbondanzo S, Lucian L, Geissler R, Brodie S, Kimball AB, et al: IL-23 stimulates epidermal hyperplasia via TNF and IL-20R2-dependent mechanisms with implications for psoriasis pathogenesis. J Exp Med 203: 2577-2587, 2006.

93. Chamian F, Lowes MA, Lin SL, Lee E, Kikuchi T, Gilleaudeau P, Sullivan-Whalen M, Cardinale I, Khatcherian A, Novitskaya I, et al: Alefacept reduces infiltrating T cells, activated dendritic cells, and inflammatory genes in psoriasis vulgaris. Proc Natl Acad Sci USA 102: 2075-2080, 2005.

94. Rizzo HL, Kagami S, Phillips KG, Kurtz SE, Jacques SL and Blauvelt A: IL-23-mediated psoriasis-like epidermal hyperplasia is dependent on IL-17A. J Immunol 186: 1495-1502, 2011

95.Zheng Y, Danilenko DM, Valdez P, Kasman I, Eastham-Anderson J, Wu J and Ouyang W: Interleukin-22, a $\mathrm{T}(\mathrm{H}) 17$ cytokine, mediates IL-23-induced dermal inflammation and acanthosis. Nature 445: 648-651, 2007.

96. Tonel G, Conrad C, Laggner U, Di Meglio P, Grys K, McClanahan TK, Blumenschein WM, Qin JZ, Xin H, Oldham E, et al: Cutting edge: A critical functional role for IL-23 in psoriasis. J Immunol 185: 5688-5691, 2010.

97. Lowes MA, Kikuchi T, Fuentes-Duculan J, Cardinale I, Zaba LC, Haider AS, Bowman EP and Krueger JG: Psoriasis vulgaris lesions contain discrete populations of Th1 and Th17 T cells. J Invest Dermatol 128: 1207-1211, 2008.

98. Szabo SK, Hammerberg C, Yoshida Y, Bata-Csorgo Z and Cooper KD: Identification and quantitation of interferon-gamma Producing T cells in psoriatic lesions: Localization to Both CD4+ and CD8+ Subsets. J Invest Dermatol 111: 1072-1078, 1998.

99. Kulig P, Musiol S, Freiberger SN, Schreiner B, Gyülveszi G, Russo G, Pantelyushin S, Kishihara K, Alessandrini F, Kündig T, et al: IL-12 protects from psoriasiform skin inflammation. Nat Commun 7: 13466, 2016

100. Krueger GG, Langley RG, Leonardi C, Yeilding N, Guzzo C, Wang Y, Dooley LT and Lebwohl M; CNTO 1275 Psoriasis Study Group: A human interleukin-12/23 monoclonal antibody for the treatment of psoriasis. N Engl J Med 356: 580-592, 2007.

101. Lanna C, Mancini M, Gaziano R, Cannizzaro MV, Galluzzo M, Talamonti M, Rovella V, Annicchiarico-Petruzzelli M, Melino G, Wang Y, et al: Skin immunity and its dysregulation in psoriasis. Cell Cycle 18: 2581-2589, 2019.

102. Nikaein A, Phillips C, Gilbert SC, Savino D, Silverman A, Stone MJ and Menter A: Characterization of skin-infiltrating lymphocytes in patients with psoriasis. J Invest Dermatol 96 3-9, 1991.

103. Nickoloff BJ and Wrone-Smith T: Injection of pre-psoriatic skin with CD4+ T cells induces psoriasis. Am J Pathol 155: 145-158, 1999.
104. Gottlieb AB, Lebwohl M, Shirin S, Sherr A, Gilleaudeau P, Singer G, Solodkina G, Grossman R, Gisoldi E, Phillips S, et al: Anti-CD4 monoclonal antibody treatment of moderate to severe psoriasis vulgaris: Results of a pilot, multicenter, multiple-dose, placebo-controlled study. J Am Acad Dermatol 43: 595-604, 2000.

105. Di Cesare A, Di Meglio P and Nestle FO: The IL-23/Th17 axis in the immunopathogenesis of psoriasis. J Invest Dermatol 129: 1339-1350, 2009.

106. Chiricozzi A, Guttman-Yassky E, Suárez-Fariñas M, Nograles KE, Tian S, Cardinale I, Chimenti S and Krueger JG: Integrative responses to IL-17 and TNF- $\alpha$ in human keratinocytes account for key inflammatory pathogenic circuits in psoriasis. J Invest Dermatol 131: 677-687, 2011.

107. Harper EG, Guo C, Rizzo H, Lillis JV, Kurtz SE, Skorcheva I, Purdy D, Fitch E, Iordanov M and Blauvelt A: Th17 cytokines stimulate CCL20 expression in keratinocytes in vitro and in vivo: Implications for psoriasis pathogenesis. J Invest Dermatol 129: 2175-2183, 2009.

108. Teunissen MB, Koomen CW, de Waal Malefyt R, Wierenga EA and Bos JD: Interleukin-17 and interferon-gamma synergize in the enhancement of proinflammatory cytokine production by human keratinocytes. J Invest Dermatol 111: 645-649, 1998.

109. Kagami S, Rizzo HL, Lee JJ, Koguchi Y and Blauvelt A: Circulating Th17, Th22, and Th1 cells are increased in psoriasis. J Invest Dermatol 130: 1373-1383, 2010.

110. Tesmer LA, Lundy SK, Sarkar S and Fox DA: Th17 cells in human disease. Immunol Rev 223: 87-113, 2008.

111. Priyadarssini M, Divya Priya D, Indhumathi S, Rajappa M, Chandrashekar L and Thappa DM: Immunophenotyping of $\mathrm{T}$ cells in the peripheral circulation in psoriasis. Br J Biomed Sci 73: 174-179, 2016.

112. Langley RG, Elewski BE, Lebwohl M, Reich K, Griffiths CEM, Papp K, Puig L, Nakagawa H, Spelman L, Sigurgeirsson B, et al: Secukinumab in plaque psoriasis-results of two phase 3 trials. N Engl J Med 371: 326-338, 2014.

113. Gordon KB, Blauvelt A, Papp KA, Langley RG, Luger T, Ohtsuki M, Reich K, Amato D, Ball SG, Braun DK, et al: Phase 3 trials of Ixekizumab in Moderate-to-Severe plaque psoriasis. N Engl J Med 375: 345-356, 2016

114. Papp KA, Merola JF, Gottlieb AB, Griffiths CEM, Cross N, Peterson L, Cioffi $\mathrm{C}$ and Blauvelt A: Dual neutralization of both interleukin $17 \mathrm{~A}$ and interleukin $17 \mathrm{~F}$ with bimekizumab in patients with psoriasis: Results from BE ABLE 1, a 12-week randomized, double-blinded, placebo-controlled phase $2 \mathrm{~b}$ trial. J Am Acad Dermatol 79: 277-286.e10, 2018

115. Lebwohl M, Strober B, Menter A, Gordon K, Weglowska J, Puig L, Papp K, Spelman L, Toth D, Kerdel F, et al: Phase 3 studies comparing brodalumab with ustekinumab in psoriasis. N Engl J Med 373: 1318-1328, 2015.

116. Blauvelt A: T-Helper 17 cells in psoriatic plaques and additional genetic links between IL-23 and Psoriasis. J Invest Dermatol 128: 1064-1067, 2008

117. Papp KA, Blauvelt A, Bukhalo M, Gooderham M, Krueger JG, Lacour JP, Menter A, Philipp S, Sofen H, Tyring S, et al: Risankizumab versus Ustekinumab for Moderate-to-severe plaque psoriasis. N Engl J Med 376: 1551-1560, 2017.

118. Kurzeja M, Rudnicka L and Olszewska M: New interleukin-23 pathway inhibitors in dermatology: Ustekinumab, briakinumab, and secukinumab. Am J Clin Dermatol 12: 113-125, 2011.

119. Alunno A, Carubbi F, Cafaro G, Pucci G, Battista F, Bartoloni E Giacomelli R, Schillaci G and Gerli R: Targeting the IL-23/IL-17 axis for the treatment of psoriasis and psoriatic arthritis. Expert Opin Biol Ther 15: 1727-1737, 2015.

120. Papp KA, Menter A, Strober B, Langley RG, Buonanno M, Wolk R, Gupta P, Krishnaswami S, Tan H and Harness JA: Efficacy and safety of tofacitinib, an oral Janus kinase inhibitor, in the treatment of psoriasis: A Phase $2 \mathrm{~b}$ randomized placebo-controlled dose-ranging study. Br J Dermatol 167: 668-677, 2012

121. Papp K, Gordon K, Thaçi D, Morita A, Gooderham M, Foley P, Girgis IG, Kundu S and Banerjee S: Phase 2 Trial of selective tyrosine kinase 2 inhibition in psoriasis. N Engl J Med 379: 1313-1321, 2018

122. Papp KA, Menter MA, Raman M, Disch D, Schlichting DE, Gaich C, Macias W, Zhang X and Janes JM: A randomized phase $2 b$ trial of baricitinib, an oral Janus kinase (JAK) 1/JAK2 inhibitor, in patients with moderate-to-severe psoriasis. $\mathrm{Br}$ J Dermatol 174: 1266-1276, 2016.

123. Murphy KM and Reiner SL: The lineage decisions of helper T cells. Nat Rev Immunol 2: 933-944, 2002 
124. Wei L, Debets R, Hegmans JJ, Benner R and Prens EP: IL-1 beta and IFN-gamma induce the regenerative epidermal phenotype of psoriasis in the transwell skin organ culture system. IFN-gamma up-regulates the expression of keratin 17 and keratinocyte transglutaminase via endogenous IL-1 production. J Pathol 187: 358-364, 1999.

125. Haider AS, Cohen J, Fei J, Zaba LC, Cardinale I, Toyoko K, Ott $\mathrm{J}$ and Krueger JG: Insights into gene modulation by therapeutic TNF and IFNgamma antibodies: TNF regulates IFNgamma production by T cells and TNF-regulated genes linked to psoriasis transcriptome. J Invest Dermatol 128: 655-666, 2008

126. Conrad C, Boyman O, Tonel G, Tun-Kyi A, Laggner U, de Fougerolles A, Kotelianski V, Gardner H and Nestle FO: Alphalbetal integrin is crucial for accumulation of epidermal $\mathrm{T}$ cells and the development of psoriasis. Nat Med 13: 836-842, 2007.

127. Ortega C, Fernández-A S, Carrillo JM, Romero P, Molina IJ, Moreno JC and Santamaría M: IL-17-producing CD8+ T lymphocytes from psoriasis skin plaques are cytotoxic effector cells that secrete Th17-related cytokines. J Leukoc Biol 86: 435-443, 2009.

128. Liang Y, Pan HF and Ye DQ: IL-17A-producing CD8(+)T cells as therapeutic targets in autoimmunity. Expert Opin Ther Targets 19: 651-661, 2015.

129. Opferman JT and Kothari A: Anti-apoptotic BCL-2 family members in development. Cell Death Differ 25: 37-45, 2018.

130. Pekarsky Y, Balatti V and Croce CM: BCL2 and miR-15/16: From gene discovery to treatment. Cell Death Differ 25: 21-26, 2018.

131. Montero J and Letai A: Why do BCL-2 inhibitors work and where should we use them in the clinic? Cell Death Differ 25: 56-64, 2018

132. Rose AM, Sansom OJ and Inman GJ: Loss of TGF- $\beta$ signaling drives cSCC from skin stem cells-More evidence. Cell Cycle 16: 386-387, 2017.

133. Yuan Y, Ding D, Zhang N, Xia Z, Wang J, Yang H, Guo F and Li B: TNF- $\alpha$ induces autophagy through ERK1/2 pathway to regulate apoptosis in neonatal necrotizing enterocolitis model cells IEC-6. Cell Cycle 17: 1390-1402, 2018

134. Schlaak JF, Buslau M, Jochum W, Hermann E, Girndt M, Gallati H, Meyer zum Büschenfelde KH and Fleischer B: T cells involved in psoriasis vulgaris belong to the Th1 subset. J Invest Dermatol 102: 145-149, 1994.

135. Jacob SE, Nassiri M, Kerdel FA and Vincek V: Simultaneous measurement of multiple Th1 and Th2 serum cytokines in psoriasis and correlation with disease severity. Mediators Inflamm 12: 309-313, 2003.

136. Fierlbeck G, Rassner G and Müller C: Psoriasis induced at the injection site of recombinant interferon gamma: Results of immunohistologic investigations. Arch Dermatol 126: 351-355, 1990.

137. Cheuk S, Wikén M, Blomqvist L, Nylén S, Talme T, Ståhle M and Eidsmo L: Epidermal Th22 and Tc17 cells form a localized disease memory in clinically healed psoriasis. J Immunol 192: 3111-3120, 2014

138. Lin WJ, Norris DA, Achziger M, Kotzin BL and Tomkinson B: Oligoclonal expansion of intraepidermal T cells in psoriasis skin lesions. J Invest Dermatol 117: 1546-1553, 2001.

139. Takamura S: Niches for the long-term maintenance of tissue-resident memory T cells. Front Immunol 9: 1214, 2018.

140. Wu H, Liao W, Li Q, Long H, Yin H, Zhao M, Chan V, Lau CS and Lu Q: Pathogenic role of tissue-resident memory T cells in autoimmune diseases. Autoimmun Rev 17: 906-911, 2018.

141. Clark RA, Chong B, Mirchandani N, Brinster NK, Yamanaka KI, Dowgiert RK and Kupper TS: The vast majority of CLA+ T cells are resident in normal skin. J Immunol 176: 4431-4439, 2006.

142. Casey KA, Fraser KA, Schenkel JM, Moran A, Abt MC, Beura LK, Lucas PJ, Artis D, Wherry EJ, Hogquist K, et al: Antigen-independent differentiation and maintenance of effector-like resident memory T cells in tissues. J Immunol 188 : 4866-4875, 2012.

143. Mackay LK, Rahimpour A, Ma JZ, Collins N, Stock AT, Hafon ML, Vega-Ramos J, Lauzurica P, Mueller SN, Stefanovic T, et al: The developmental pathway for CD103(+) CD8+ tissue-resident memory T cells of skin. Nat Immunol 14: 1294-1301, 2013.

144. Owczarczyk Saczonek A, Krajewska-Włodarczyk M, Kasprowicz-Furmańczyk M and Placek W: Immunological memory of psoriatic lesions. Int J Mol Sci 21: 625, 2020.
145. Milner JJ and Goldrath AW: Transcriptional programming of tissue-resident memory CD8+ T cells. Curr Opin Immunol 51: 162-169, 2018.

146. Eberle FC, Brück J, Holstein J, Hirahara K and Ghoreschi K: Recent advances in understanding psoriasis. F1000Res 5: F1000 Faculty Rev-770, 2016

147. Patra V, Laoubi L, Nicolas JF, Vocanson M and Wolf P: A Perspective on the interplay of ultraviolet-radiation, skin microbiome and skin resident memory TCR $\alpha \beta+$ cells. Front Med (Lausanne) 5: 166, 2018.

148. Clark RA: Resident memory $\mathrm{T}$ cells in human health and disease. Sci Transl Med 7: 269rv1, 2015.

149. Mueller SN, Zaid A and Carbone FR: Tissue-Resident T Cells: Dynamic players in skin immunity. Front Immunol 5: 332, 2014.

150. Corgnac S, Boutet M, Kfoury M, Naltet C and Mami-Chouaib F: The Emerging Role of CD8+ tissue resident memory T (TRM) cells in antitumor immunity: A unique functional contribution of the CD103 integrin. Front Immunol 9: 1904, 2018.

151. Kurihara K, Fujiyama T, Phadungsaksawasdi $\mathrm{P}$, Ito $\mathrm{T}$ and Tokura Y: Significance of IL-17A-producing CD8+CD103+ skin resident memory $\mathrm{T}$ cells in psoriasis lesion and their possible relationship to clinical course. J Dermatol Sci 95: 21-27, 2019.

152. Walsh D, Borges da Silva H, Beura L, Peng C, Hamilton S, Masopust D and Jameson S: The functional requirement for CD69 in establishment of resident memory CD8 + T cells varies with tissue location. J Immunol 203: 946-955, 2019.

153. Mackay LK, Braun A, Macleod BL, Collins N, Tebartz C, Bedoui S, Carbone FR and Gebhardt T: Cutting edge: CD69 interference with sphingosine-1-phosphate receptor function regulates peripheral T cell retention. J Immunol 194: 2059-2063, 2015.

154. Schenkel JM and Masopust D: Tissue-resident memory T cells. Immunity 41: 886-897, 2014

155. Cheuk S, Schlums H, Gallais Sérézal I, Martini E, Chiang SC, Marquardt N, Gibbs A, Detlofsson E, Introini A, Forkel M, et al: CD49a expression defines Tissue-resident CD8+ T cells poised for cytotoxic function in human skin. Immunity 46: 287-300, 2017.

156. Seidel JA, Vukmanovic-Stejic M, Muller-Durovic B, Patel N, Fuentes-Duculan J, Henson SM, Krueger JG, Rustin MHA, Nestle FO, Lacy KE and Akbar AN: Skin resident memory $\mathrm{CD}^{+} \mathrm{T}$ cells are phenotypically and functionally distinct from circulating populations and lack immediate cytotoxic function. Clin Exp Immunol 194: 79-92, 2018.

157. Petrelli A and van Wijk F: CD8(+) T cells in human autoimmune arthritis: The unusual suspects. Nat Rev Rheumatol 12: 421-428, 2016.

158. Ritchlin C: Tissue-resident memory T cells: Sequestered immune sensors and effectors of inflammation in Spondyloarthritis Arthritis Rheumatol 72: 379-382, 2020

159. Adachi T, Kobayashi T, Sugihara E, Yamada T, Ikuta K, Pittaluga S, Saya H, Amagai $M$ and Nagao K: Hair follicle-derived IL-7 and IL-15 mediate skin-resident memory T cell homeostasis and lymphoma. Nat Med 21: 1272-1279, 2015.

160. Diani M, Galasso M, Cozzi C, Sgambelluri F, Altomare A, Cigni C, Frigerio E, Drago L, Volinia S, Granucci F, et al: Blood to skin recirculation of $\mathrm{CD} 4+$ memory $\mathrm{T}$ cells associates with cutaneous and systemic manifestations of psoriatic disease. Clin Immunol 180: 84-94, 2017.

161. Matos TR, O'Malley JT, Lowry EL, Hamm D, Kirsch IR, Robins HS, Kupper TS, Krueger JG and Clark RA: Clinically resolved psoriatic lesions contain psoriasis-specific IL-17-producing $\alpha \beta \mathrm{T}$ cell clones. J Clin Invest 127: 4031-4041, 2017.

162. Meglio PD, Villanova F, Navarini AA, Mylonas A, Tosi I, Nestle FO and Conrad C: Targeting CD8+ T cells prevents psoriasis development. J Allergy Clin Immunol 138: 274-276. e6, 2016.

163. Farber DL, Yudanin NA and Restifo NP: Human memory T cells: Generation, compartmentalization and homeostasis. Nat Rev Immunol 14: 24-35, 2014

164. Boyman O, Hefti HP, Conrad C, Nickoloff BJ, Suter M and Nestle FO: Spontaneous development of psoriasis in a new animal model shows an essential role for resident $T$ cells and tumor necrosis Factor-alpha. J Exp Med 199: 731-736, 2004.

165. Campbell JJ, Clark RA, Watanabe R and Kupper TS: Sezary syndrome and mycosis fungoides arise from distinct T-cell subsets: A biologic rationale for their distinct clinical behaviors. Blood 116: 767-771, 2010. 
166. Gallais Sérézal I, Classon C, Cheuk S, Barrientos-Somarribas M Wadman E, Martini E, Chang D, Landén NX, Ehrström M, Nylén $\mathrm{S}$ and Eidsmo L: Resident T cells in resolved psoriasis steer tissue responses that stratify clinical outcome. J Invest Dermatol 138: 1754-1763, 2018.

167. Sérézal IG, Hoffer E, Ignatov B, Martini E, Zitti B, Ehrström M and Eidsmo L: A skewed pool of resident $\mathrm{T}$ cells triggers psoriasis-associated tissue responses in never-lesional skin from patients with psoriasis. J Allergy Clin Immunol 143: 1444-1454, 2019.

168. Vo S, Watanabe R, Koguchi-Yoshioka H, Matsumura Y, Ishitsuka Y, Nakamura Y, Okiyama N, Fujisawa Y and Fujimoto M: CD8 resident memory $\mathrm{T}$ cells with interleukin 17A-producing potential are accumulated in disease-naïve nonlesional sites of psoriasis possibly in correlation with disease duration. Br J Dermatol 181: 410-412, 2019.

169. Diani M, Altomare G and Reali E: T Helper cell subsets in clinical manifestations of psoriasis. J Immunol Res 2016: e7692024, 2016

170. Bosè F, Petti L, Diani M, Moscheni C, Molteni S, Altomare A, Rossi RL, Talarico D, Fontana R, Russo V, et al: Inhibition of CCR7/CCL19 axis in lesional skin is a critical event for clinical remission induced by TNF blockade in patients with psoriasis. Am J Pathol 183: 413-421, 2013.

171. Watanabe R: Protective and pathogenic roles of resident memory $\mathrm{T}$ cells in human skin disorders. J Dermatol Sci 95: 2-7, 2019.

172. Sgambelluri F, Diani M, Altomare A, Frigerio E, Drago L, Granucci F, Banfi G, Altomare $G$ and Reali E: A role for CCR5(+)CD4 T cells in cutaneous psoriasis and for CD103(+) CCR4(+) CD8 Teff cells in the associated systemic inflammation. J Autoimmun 70: 80-90, 2016.
173. Chen L and Shen Z: Tissue-resident memory $\mathrm{T}$ cells and their biological characteristics in the recurrence of inflammatory skin disorders. Cell Mol Immunol 17: 64-75, 2020.

174. Pan Y and Kupper TS: Metabolic reprogramming and longevity of tissue-resident memory T cells. Front Immunol 9: 1347, 2018

175. Pearce EL, Walsh MC, Cejas PJ, Harms GM, Shen H, Wang LS, Jones RG and Choi Y: Enhancing CD8 T-cell memory by modulating fatty acid metabolism. Nature 460: 103-107, 2009.

176. Cui G, Staron MM, Gray SM, Ho PC, Amezquita RA, Wu J and Kaech SM: IL-7-induced glycerol transport and TAG synthesis promotes memory CD8+ T cell longevity. Cell 161: 750-761, 2015.

177. Pan Y, Tian T, Park CO, Lofftus SY, Mei S, Liu X, Luo C, O'Malley JT, Gehad A, Teague JE, et al: Survival of tissueresident memory $\mathrm{T}$ cells requires exogenous lipid uptake and metabolism. Nature 543: 252-256, 2017.

178. Esmaeili B, Mansouri P, Doustimotlagh AH and Izad M: Redox imbalance and IL-17 responses in memory CD $4^{+} \mathrm{T}$ cells from patients with psoriasis. Scand J Immunol 89: e12730, 2019.

179. Karamehic J, Zecevic L, Resic H, Jukic M, Jukic T, Ridjic O, Panjeta $\mathrm{M}$ and Coric J: Immunophenotype lymphocyte of peripheral blood in patients with psoriasis. Med Arch 68: 236-238, 2014

This work is licensed under a Creative Common Attribution-NonCommercial-NoDerivatives 4.0 International (CC BY-NC-ND 4.0) License. 